\title{
Sosialisasi Bantuan Hukum dan Pelatihan Pembuatan Pledoi Sebagai Pemenuhan Hak Terdakwa di Rumah Tahanan Boyolali
}

\author{
Rizal Pambudi', Winda Permata Sari², Marisa Kurnianingsih 3 , Aristya Windiana \\ Pamuncak $^{4}$, Andria Luhur Prakoso 5 , Muchamad Iksan 6 \\ 123456 Fakultas Hukum, Universitas Muhammadiyah Surakarta \\ * Email korespondensi: mk122@ums.ac.id (+67 8572515 1010)
}

Received: 30 Desember 2020; Revision: 10 Februari 2021; Accepted: 30 Maret 2021

\begin{abstract}
Abstrak
Pledoi adalah suatu tahap pembelaan yang dilakukan terdakwa untuk dapat melakukan sanggahannya mengenai tuntutan yang dituntutkan oleh penuntut umum. Di dalam undang-undang telah mengatur mengenai pledoi didalam pemeriksaa sidang pengadilan, yakni pada pasal 182 ayat 1 KUHAP. Walaupun tidak secara menyeluruh pembahasannya, namun cukup jelas untuk dapat dimengerti. Pledoi ini dilakukan secara tertulis dan dibacakan di muka persidangan. Tujuan pledoi sendiri adalah untuk meminta putusan bebas atau lepas dari segala tuntutan hukum. Namun, dalam pakteknya masih dapat ditemui kesalahpahaman dalam melakukan pledoi ini, seperti isi dari pledoi itu sendiri hanya meminta keringanan hukuman saja dan juga masih terdapat pledoi yang dilakukan secara lisan dalam persidangan. Kegiatan pengabdian kepada masyarakat ini membantu memberi pemahaman kepada peserta mengenai hak terdakwa dan memberikan pemahaman mengenai pembuatan pledoi. Sosialisai ini bertujuan untuk memberikan pelatihan bagi Terdakwa di Rumah Tahanan Kelas IIB Boyolali agar para Terdakwa mengetahui dan sadar betapa pentingnya Pembelaan/Pledoi atas tuntutan Jaksa Penuntut Umum. Bahkan jika Terdakwa tidak didampingi oleh penasehat hukum pun mereka mampu memperjuangkan haknya untuk melakukan Pembelaan atas tuntutan Jaksa Penuntut Umum. Pemenuhan hak Terdakwa akan memberikan rasa keadilan dalam persidangan.
\end{abstract}

Kata Kunci : Hukum, Pledoi, Terdakwa,

Pambudi, R., Sari, W., Kurnianingsih, M., Pamuncak, A., Prakoso, A., \& Iksan, M. (2021). Sosialisasi Bantuan Hukum dan Pelatihan Pembuatan Pledoi Sebagai Pemenuhan Hak Terdakwa di Rumah Tahanan Boyolali. Masyarakat Berdaya dan Inovasi, 2(1). doi:https://doi.org/10.33292/mayadani.v2i1.58

This is an open access article under the CC-BY-SA license.

PENDAHULUAN

Negara Indonesia adalah Negara hukum, ketentuan ini tercantum dalam Pasal 1 ayat (3) hasil amandemen keempat Undang-Undang Dasar 1945 (selanjutnya disingkat UUD 1945), yang menyatakan "Negara Indonesia adalah Negara hukum”. Jika dilihat ketentuan tersebut, maka semua aspek kehidupan baik dibidang sosial, politik, budaya, ekonomi diatur dan dibatasi oleh norma-norma hukum yang berlaku (Rifai 2014). Hukum pada dasarnya 
dibuat dengan tujuan untuk dapat memberikan perlindungan dan ketertiban di dalam masyarakat supaya terciptanya keadilan bagi semua lapisan masyarakat. Akan tatapi dalam prakteknya masih banyak ditemukan pelanggaran pelanggaran serta penyimpanganpenyimpangan terhadap tujuan hukum itu sendiri, baik disengaja maupun tidak disengaja (Paramitha 2020). Pengadilan sebagai lembaga penegak hukum merupakan bagian dari sistem peradilan pidana menjadi tempat untuk mencari keadilan bagi para pencari keadilan dengan keinginan agar peradilan dilaksanakan secara sederhana, dengan proses yang cepat dan dengan pembiayaan yang murah (Suriani and Ismail 2020). Menurut Kamus Besar Bahasa Indonesia istilah Terdakwa berasal dari kata "Dakwa" yakni tuduhan, atau dapat dijabarkan dengan suatu pengaduan atau tuntutan yang diajukan kepada hakim. Sedangan untuk kata "terdakwa" sendiri ialah orang yang didakwa (dituntut atau dituduh) telah melakukan tidak pidana dan adanya cukup alasan untuk dilakukan pemeriksaan di muka persidangan. Dakwaan JPU terhadap terdakwa berbentuk subsidiaritas, maka dari itu Majelis Hakim mempertimbangkan dakwaan primar terlebih dahulu (Hamzah 2012). Hak daritersangka atau terdakwa pidana untuk mendapatkan pembelaan hukum merupakan suatu hak fundamental yang dijamin oleh hukum dan negara kepada tersangka atau terdakwa dari suatu tindak pidana untuk mendapatkan pembelaan hukum dari seorang pembela yang terakreditasi. Menurut KUHAP Pasal 1 butir 15 menerangkan mengenai pengertian Terdakwa, yakni: "Terdakwa adalah seseorang tersangka yang dituntut, diperiksa dan diadili di sidang pengadilan'(Munir and Fuady 2015).

Terdakwa memiliki beberapa hak yang diperolehnya selama berjalananya persidangan yang terkait oleh pemeriksaan terdakwa di Pengadilan, Berikut hak-hak terdakwa didalam pasal 50-68 KUHAP, antara lain:

a. Pasal 50: Hak untuk diperiksa, diajukan ke pengadilan, dan dialidi

b. Pasal 51: hak untuk mengetahui dnegan jelas dan bahasa yang dimengerti oelhnya tentang apa yang disangkakan dan apa yang didakwakan

c. Pasal 52: hak untuk memberikan keterangan secara bebas kepada penyidik dan hakim seperti tersebut dimuka

d. Pasal 53 ayat 1: hak untuk mendapatkan juru bahasa

e. Pasal 54-56: hak untuk mendapatkan bantuan hukum pada setiap tingkat pemeriksaan

f. Pasal 65: hak tersangka atau terdakwa untuk mengajukan saksi dan ahli a de charge

g. Pasal 68: hak tersangka atau terdakwa untuk menuntut ganti kerugian.

Dari sekian hak-hak terdakwa yang di atur dalam KUHAP terdapat juga hak terdakwa didalam persidangan untuk melakukan pembelaan atau disebut dengan Pledoi.Pembelaan dapat dilakukan setelah Jaksa Penuntut Umum selesai membacakan surat tuntutannya (Undang-Undang 1981). Pembelaan (Pledoi) bertujuan untuk mendapatkan putusan hakim 
yang dapat membebaskan terdakwa dari segala dakwaan dan atau dapat melepaskan terdakwa dari segala tuntutan hukum (Effendi 2016).

Praktiknya masih banyak ditemui Terdakwa yang tidak membuat Pembelaan/Pledoi atas tuntutan Jaksa Penuntut Umum, hal ini dikarenakan ketidaktahuan Terdakwa khususnya Terdakwa yang tidak didampingi oleh Penasihat Hukum, maka dengan demikian ada salah satu Hak Terdakwa yang hilang.

Melihat permasalahan tersebut maka dilakukan Sosialisasi di Rumah Tahanan Boyolali dengan judul 'S Sosialisasi Bantuan Hukum dan Pelatihan Pembuatan Pledoi Sebagai Pemenuhan Hak Terdakwa di Rumah Tahanan Boyolali', Sosialisai ini bertujuan untuk memberikan pengetahuan bagi Terdakwa di Rumah Tahanan boyolali agar para Terdakwa mengetahui dan sadar betapa pentingnya Pembelaan/Pledoi atas tuntutan Jaksa Penuntut Umum, maka dari itu Hak untuk melakukan Pembelaan atas tuntutan Jaksa Penuntut Umum tidak hilang.

\section{METODE}

Pendekatan yang digunakan adalah metode sosialisasi. Lewat proses sosialisasi, Terdakwa yang berada di Rumah Tahanan Boyolali dapat mengetahui betapa pentingnya Pledoi untuk menjamin Hak mereka terpenuhi, selain itu dengan Pelatihan Pembuatan Pledoi tersebut Terdakwa dapat membuat Pledoi walaupun tidak didampingi dengan Penasihat Hukum. Materi Sosialisasi mencakup:

1. Hak-hak terdakwa sesuai dengan KUHAP.

2. Pengertian dan Tujuan Pembuatan Pledoi sesuai dengan pasal 182 ayat 1 KUHAP

3. Sistematika pembuatan Pledoi

4. Kapan Pledoi dibuat

Kegiatan ini dilaksanakan kerja sama antara Badan Konsultasi dan Bantuan Hukum (BKBH) Fakultas Hukum Universitas Muhammadiyah Surakarta dengan Rumah Tahanan Boyolali dan dilaksanakan di Rumah Tahanan Boyolali. Peran mitra ini ialah sebagai peserta sosialisasi serta penyedia sarana dan prasarana yang diperlukan guna menunjang telaksananya sosialisasi. Waktu pelaksanaan kegiatan ini dilaksanakan pada tanggal 06 November 2020.

\section{HASIL}

\section{HASIL DAN PEMBAHASAN}

Sejak awal perencanaan dan penyusunan proposal program pengabdianmasyarakat ini telah melibatkan mitra guna mengetahui secara pasti masalah yang dihadapi, sehingga selama 
kegiatan pengabdian masyarakat berlangsung dapat berjalan lancar dan tanpa ada kendala yang berarti. Pelaksanaan kegiatan masyarakat di Rumah Tahanan Boyolali kelas IIB berupa sosialisasi Pelatihan Pembuatan Pledoi untuk memenuhi Hak Terdakwa karena masih banyak warga yang kurang memahami pentingnya Pledoi dalam persidangan setelah Penuntut Umum membacakan tuntutannya, khususnya Terdakwa yang tidak didampingi penasehat hukum.

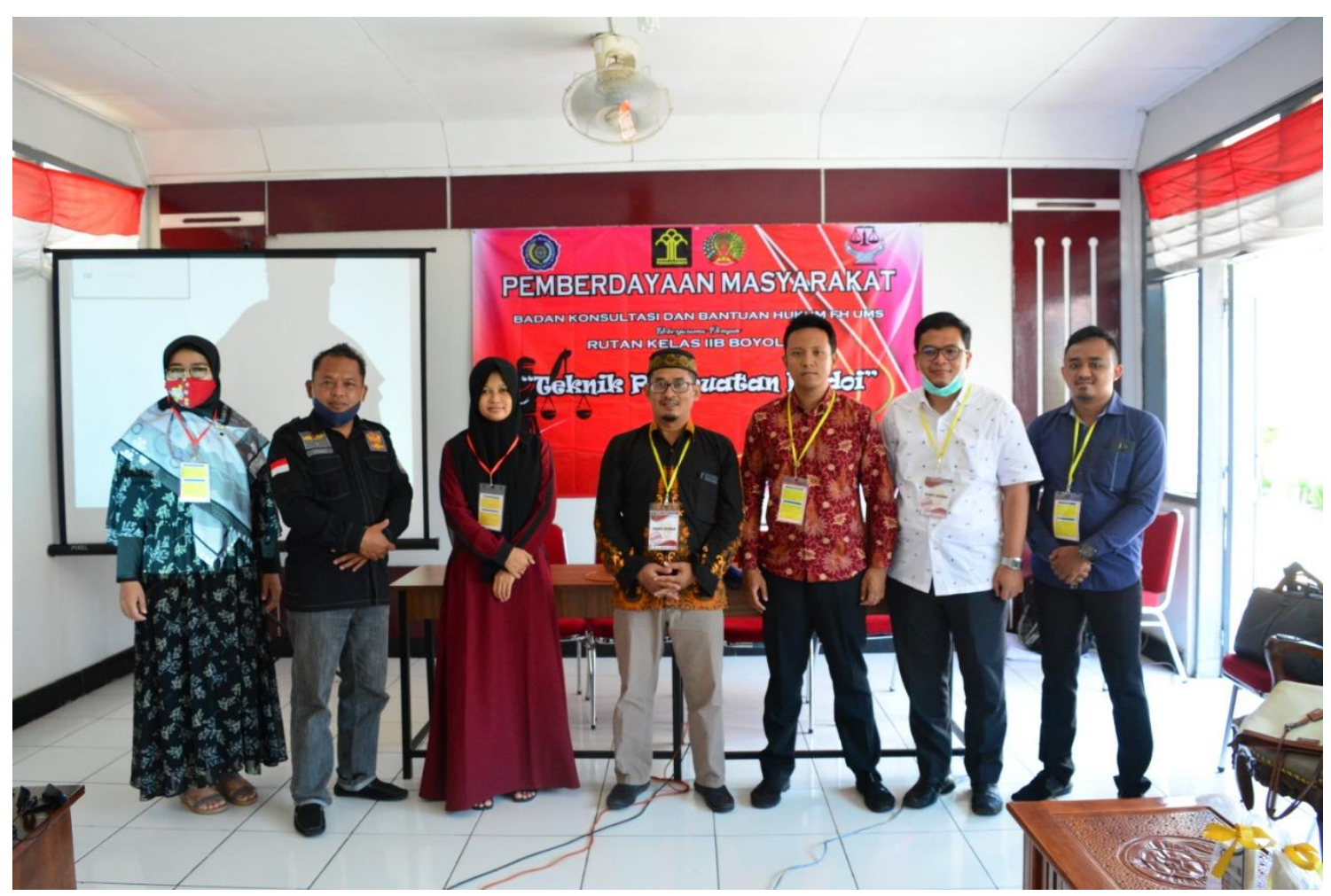

Gambar 1 Tim dan Mitra pemberi sosialisasi

\section{PEMBAHASAN}

Pelaksanaan kegiatan pengabdian masyarakat ini berupa sosialiasi tentang Pelatihan Pembuatan Pledoi Sebagai Pemenuhan Hak Terdakwa. Sosialiasasi ini melalui 3 tahap, yaitu tahap persiapan, tahap pelaksanaan, dan tahap pelaporan. Pada tahap persiapan tim mempersiapkan serta mengumpulkan materi yang dibentuk dalam power point yang akan dipresentasikan saat tahap pelaksanaan. Pada tahap pelaksanaan tim melaksanakan kegiatan sosialisasi di Rumah Tahanan Kelas IIB Boyolali yang dilaksanakan pada tanggal 06 November 2020

Pada tahap persiapan tim melaksanakan survey lapangan di lokasi yaitu Rumah Tahanan Kelas IIB Boyolali serta berdiskusi dengan perwakilan mitra guna menentukan materi yang dibutuhkan pada saat kegiatan sosialisasi dilaksanakan. Berdasarkan hasil diskusi 
tersebut akhirnya ditentukan bahwa materi yang dibutuhkan mengenai pelatihan pembuatan Pledoi sebagai pemenuhan Hak bagi Terdakwa. Materi dipilih karena Terdakwa yang berada di Rumah Tahanan Kelas IIB Boyolali masih belum paham betapa pentingnya mengajukan Pembelaan/Pledoi atas tuntutan Jaksa Penuntut Umum.

Sebelum melakukan kegiatan sosialisasi, langkah pertama yang tim lakukan ialah penyusunan materi presentasi dalam bentuk power point. Materi diambil berdasarkan referensi perundang-undangan dan jurnal-jurnal yang ada. Materi pertama menjelaskan mengenai hak-hak Terdakwa menurut KUHAP yang salah satu Hak Terdakwa tersebut adalah Terdakwa berhak didampingi penasehat hukum, bahkan jika Terdakwa tidak mampu yang diancam dengan pidana lebih dari 5 tahun maka negara harus menyediakan penasehat hukum gratis untuknya. Hal ini harus diberikan pemahaman kepada Terdakwa karena selama ini, Terdakwa banyak yang takut menggunakan penasehat hukum dengan alasan persidangan akan menjadi lama. Padahal dengan tidak didampingi penasehat hukum, Terdakwa sudah kehilangan haknya untuk menghadirkan keadilan di persidangan, yang mana seharusnya persidangan tidak berat sebelah dan Terdakwa dapat menyusun pembuktian yang meringankan.

Terdakwa memiliki beberapa hak yang diperolehnya selama berjalananya persidangan yang terkait oleh pemeriksaan terdakwa di Pengadilan, Berikut hak-hak terdakwa didalam pasal 50-68 KUHAP, antara lain:

A. Pasal 50: Hak untuk diperiksa, diajukan ke pengadilan, dan dialidi

B. Pasal 51: hak untuk mengetahui dnegan jelas dan bahasa yang dimengerti olehnya tentang apa yang disangkakan dan apa yang didakwakan

C. Pasal 52: hak untuk memberikan keterangan secara bebas kepada penyidik dan hakim seperti tersebut dimuka

D. Pasal 53 ayat 1: hak untuk mendapatkan juru bahasa

E. Pasal 54-56: hak untuk mendapatkan bantuan hukum pada setiap tingkat pemeriksaan

F. Pasal 65: hak tersangka atau terdakwa untuk mengajukan saksi dan ahli a de charge

G. Pasal 68: hak tersangka atau terdakwa untuk menuntut ganti kerugian.

Materi kedua menjelaskan Pengertian dan tujuan pembuatan Pledoi berdasarkan Pasal 182 ayat 1 KUHAP. Pengertian Pledoi adalah suatu tahap pembelaan yang dilakukan terdakwa untuk dapat melakukan sanggahannya mengenai tuntutan yang dituntutkan oleh penuntut umum. . Walaupun tidak secara menyeluruh pembahasannya, namun cukup jelas untuk dapat dimengerti. Pledoi ini dilakukan secara tertulis dan dibacakan di muka persidangan. Tujuan pledoi sendiri adalah untuk meminta putusan bebas atau lepas dari segala tuntutan hukum. Dalam materi ini dijelaskan mengeai pentingnya pledoi bagi Terdakwa. 
Materi ini bertujuan memberikan pemahaman pada peseta bahwa Pledoi merupakan salah satu hal yang sangat penting untuk dibuat, karena Pledoi ini sendiri merupakan hak bagi Terdakwa untuk mendapatkan putusan yang seadil-adilnya.

Materi ketiga menjelaskan mengenai sistematika pembuatan Pledoi, materi ini memberikan pelatihan kepada Terdakwa agar bisa membuat Pledoi sendiri jika Terdakwa tidak didampingi penasehat hukum. Dari materi ini peserta dapat membuat Pledoi secara tertulis dengan benar untuk dibacakan dimuka persidangan dan mengetahui apa saja yang harus dituliskan didalam Pledoi. Komponen yang terdapat dalam Pledoi adalah :

1. fakta-fakta yang terungkap dalam persidangan dan merupakan bagian dari pembelaan hakhak terdakwa.

2. adanya kekeliruan penuntut umum baik mengenai jenis tindak pidananya, keliru dalam menafsirkan ketentuan peraturan perundang-undangan, keliru menghubungkan keterangan saksi dengan barang bukti.

3. ada ketidak sesuai soal apa yang diuraikan dalam surat dakwaan dengan apa yang dibuktikan dalam surat tuntutan.

4. adanya pengenyampingan alat-alat bukti.

5. adanya perbedaan keterangan saksi dalam BAP dengan apa yang diterangkan saksi dalam persidangan.

6. adanya pengajuan barang bukti yang tidak relevan.

7. keterangan saksi yang melemahkan, keterangan saksi yang memberatkan dan keterangan saksi yang meringankan atau melemahkan dakwaan yang dibaikan penuntut dan lain sebagainya.

Materi keempat menjelaskan kapan Pledoi dibuat, Pada dasarnya Pledoi adalah sebuah pembelaan, maka Terdakwa dapat membuat Pledoi setelah Jaksa Penuntut Umum membacakan Tuntutannya. Dengan menjawab tuntutan diharapkan hakim memiliki pertimbangan lain dalam hal memutus perkara yang sedang dihadapi oleh Terdakwa.

Dengan adanya sosialisasi ini diharapkan Terdakwa yang berada di Rumah Tahanan Kelas IIB Boyolali dapat membuat Pledoi secara mandiri, agar Hak Terdakwa dapat terpenuhi. 
Masyarakat Berdaya dan Inovasi, 2 (1), 2021

Rizal Pambudi, Winda Permata Sari, Marisa Kurnianingsih, Aristya Windiana Pamuncak, Andria Luhur Prakoso, Muchamad Iksan

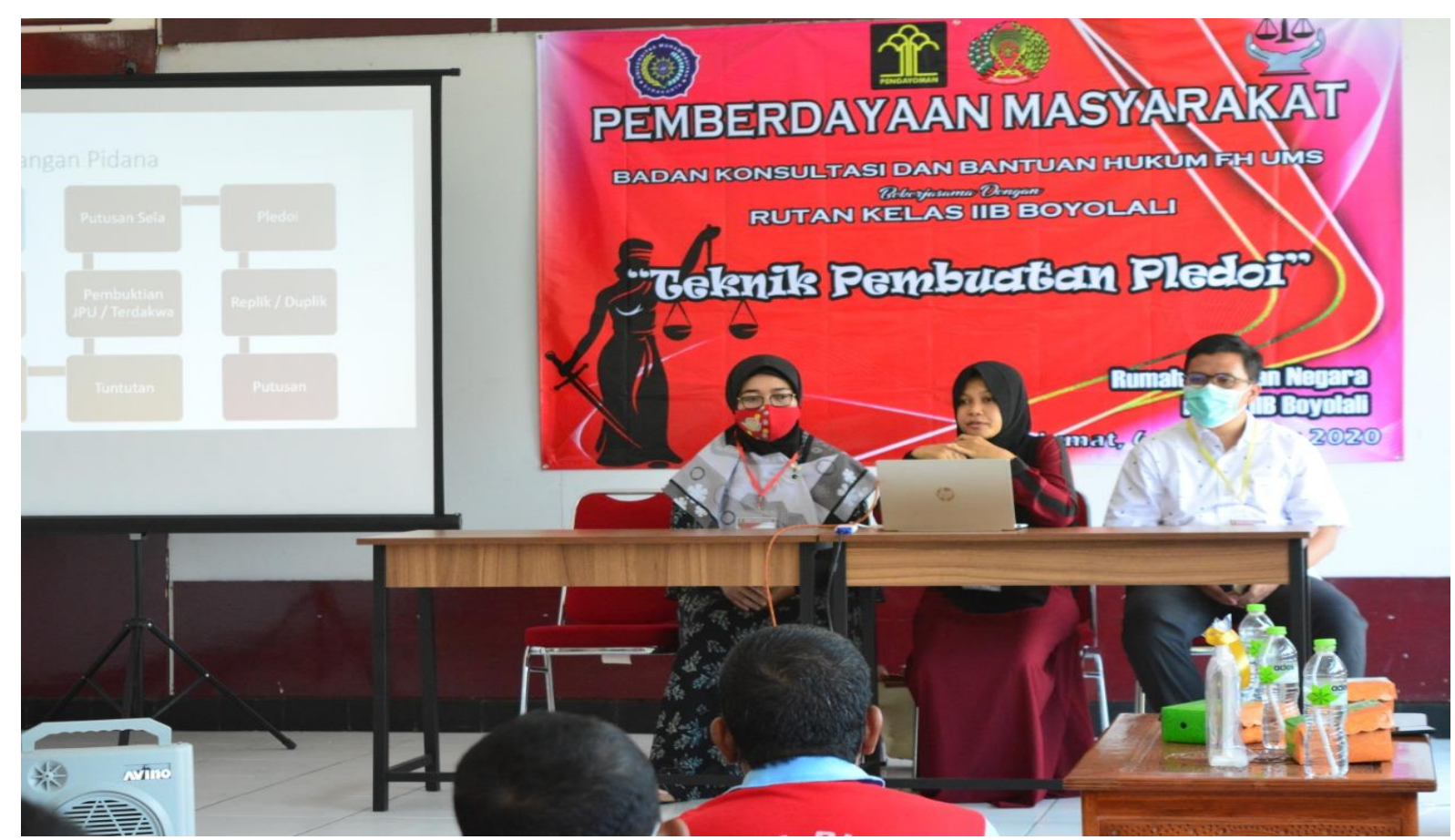

Gambar 2 memperlihatkan pada saat tim menyampaikan materi dalam bentuk power point, Penyampaian materi berlangsung di Aula Rumah Tahanan Kelas IIB Boyolali.

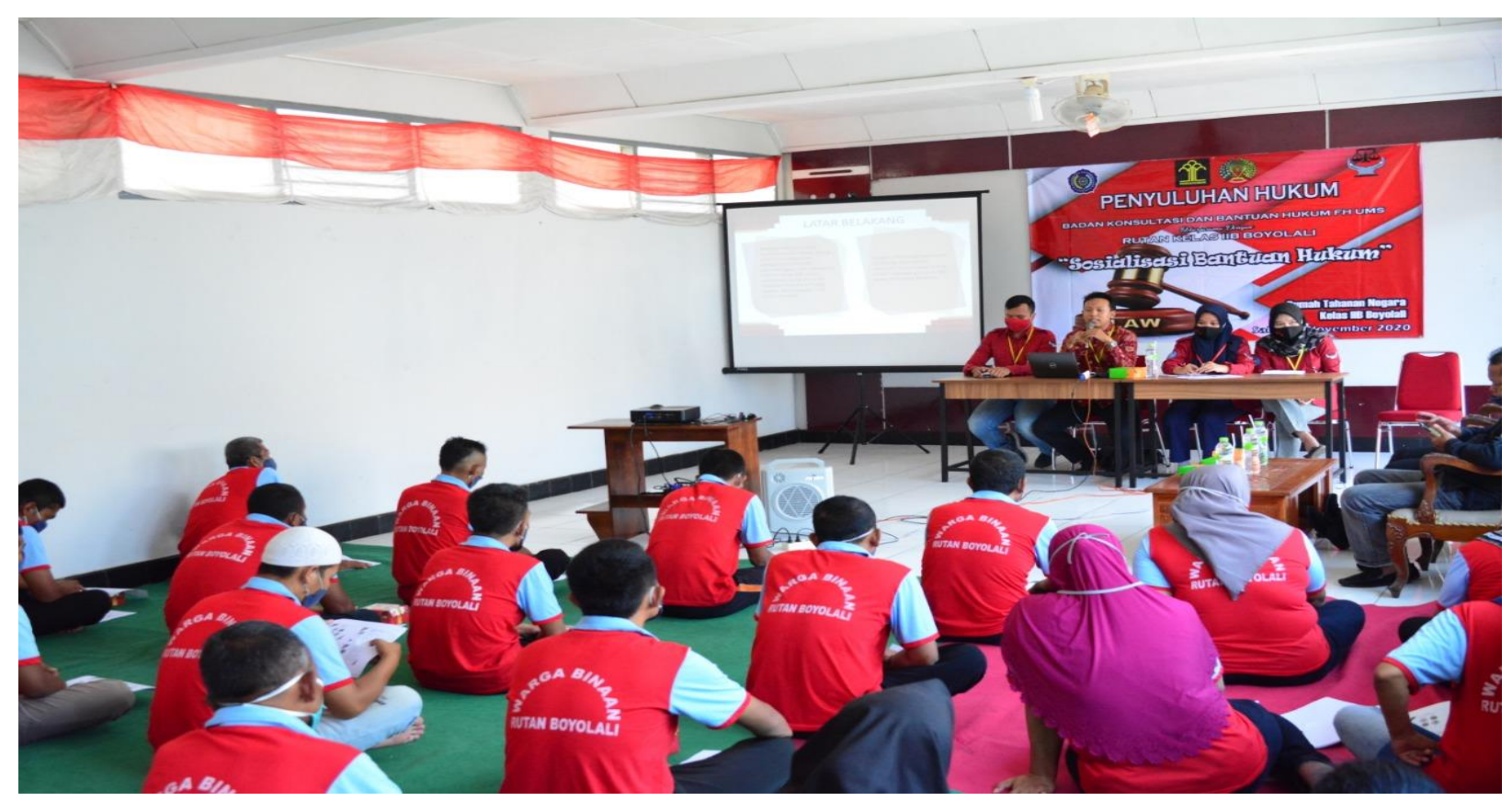

Peserta aktif memperhaikan jalannya kegiatan sosialisasi.

Setelah kegiatan sosialisasi selesai dilaksanakan, selanjutnya adalah diskusi akhir dan evaluasi oleh tim bersama dengan perwakilan mitra. Berdasarkan evaluasi diperoleh hasil yang cukup memuaskan ditandai dengan perwakilan mitra yang berterima kasih atas kegiatan sosialisasi yang dilaksanakan, dan bertambahnya pengetahuan Terdakwa mengenai haknya 
selama persidangan serta Terdakwa mempunyai bekal ilmu untuk menyusun pledoi secara mandiri. Hasil akhir dari kegiatan sosialisasi ini adalah seluruh peserta dapat mengetahui banyak penjelasan detail mengenai Pembuatan Pledoi Sebagai Pemenuhan Hak Terdakwa di Rumah Tahanan Kelas IIB Boyolali.

\section{SIMPULAN}

Kegiatan pengabdian kepada masyarakat ini membantu memberi pemahaman kepada peserta mengenai hak terdakwa dan memberikan pemahaman mengenai pembuatan pledoi. Dari sosialisasi tersebut diharapkan Terdakwa memahami hak-haknya dan Sosialisai ini bertujuan untuk memberikan pelatihan bagi Terdakwa di Rumah Tahanan Kelas IIB Boyolali agar para Terdakwa mengetahui dan sadar betapa pentingnya Pembelaan/Pledoi atas tuntutan Jaksa Penuntut Umum. Bahkan jika Terdakwa tidak didampingi oleh penasehat hukum pun mereka mampu memperjuangkan haknya untuk melakukan Pembelaan atas tuntutan Jaksa Penuntut Umum. Pemenuhan hak Terdakwa akan memberikan rasa keadilan dalam persidangan.

\section{UCAPAN TERIMA KASIH}

Program pengabdian ini dapat terlaksana dengan baik atas kerja sama dengan Rumah Tahanan kelas IIB Boyolali yang telah bersedia menjadi peserta prlatihan sekaligus sebagai tempat Pelaksanaan Pelatihan.

\section{DAFTAR PUSTAKA}

Effendi, Tolib. 2016. Praktik Peradilan Pidana Kemahiran Berbicara Pidana Pada Pengadilan Tingkat Pertama. Malang: Setara Press.

Hamzah, Andi. 2012. Hukum Acara Pidana Indonesia Edisi Kedua. Jakarta: Sinar Grafika.

Munir, Fuady, and Sylvia Laura L. Fuady. 2015. Hak Asasi Tersangka Pidana. Jakarta: PT Kharisma Putra Pratama.

Paramitha, Ade Inggit. 2020. "Pembelaan Terhadap Terdakwa Menurut Hukum Pidana Positif Dan Hukum Pidana Islam.” Al-Qanun: Jurnal Kajian Sosial Dan Hukum Islam 1(1):99-116.

Rifai, Eddy. 2014. "Perspektif Pertanggungjawaban Pidana Korporasi Sebagai Pelaku Tindak Pidana Korupsi." vol 26 no.

Suriani, and Ismail. 2020. "PENGARUH PANDEMI COVID-19 TERHADAP PELAKSANAAN Suriani , 2 Ismail I . PENDAHULUAN Penegakan Hukum Bagian Dari Usaha Yang Dilakukan Guna Menciptakan Tata Tertib Yang Dapat Memberi Rasa Aman Dan Tentram Di Dalam Masyarakat . Tindakan Preventif Maupun Tindak." (September):787-800. 
Undang-Undang. 1981. "Undang-Undang Republik Indonesia Nomor 8 Tahun 1981 Tentang Kitab Undang Undang Hukum Acara Pidana (KUHAP).” Kpk 1951(8):1-142. 